\section{Earthquake rocks Romania}

\section{London}

THE earthquake that hit Romania on 30 May was, at magnitude 6.9 , similar in severity to the 1988 Soviet Armenian earthquake, but the nine fatalities reported so far are much fewer than the tens of thousands killed in Armenia. The low Romanian death toll is partly because the earthquake was deep - the epicentre was about $90 \mathrm{~km}$ below the surface - and partly because most of the fragile buildings in the affected area had been demolished by a 7.2 magnitude earthquake in 1977 .

The Romanian earthquake, classified as 'intermediate depth', generated shock waves over a wide area and was felt about $1,300 \mathrm{~km}$ away in Moscow, but caused less ground movement at the surface than the shallow 1988 Armenian event, whose epicentre was only $3 \mathrm{~km}$ down. At $45.75^{\circ} \mathrm{N}$ and $26.65^{\circ} \mathrm{E}$, the earthquake was centred in an area called the Vrancea focus, from which the Carpathian Mountains extend in an arc to the north and the west.

According to Professor Dan McKenzie EUROPEAN SCIENCE

\section{Eureka finds Eastern}

\section{Europe}

\section{Munich}

WESTERN European industry ministers meeting in Rome last week announced that they would extend a hand to Eastern European countries interested in participating in the Eureka research and development programme. Eastern European states will not be able to join Eureka, but their involvement will be encouraged in both the planning and the execution of joint projects. Until now, Eastern European countries have been able to join Eureka projects only when they have begun.

The membership of Eureka, a flexible programme that coordinates multinational research and applied science projects in Europe, now includes Scandinavia, Austria, Switzerland, Iceland and Turkey in addition to the 12 European Communities nations. Although Yugoslavia had an earlier application to join turned down, it and two other Eastern European states, Hungary and the Soviet Union, already participate in 9 Eureka projects. East Germany is expected this year to join EUROTRAC, a project to study the path of air pollutants through Europe, and EUROMARBLE, which is concerned with the conservation of historical landmarks.

One hundred new projects were taken up by Eureka last year, making a total of about 400. Member states and companies now contribute DM16,000 million $(\$ 9,500$ million), up from DM 13,000 million a year ago. College, London, says

\section{NON-PROLIFERATION TREATY}

\section{São Paulo}

ONCE a new uranium-enriching centre is complete, all it would take for Brazil to build an atomic bomb is $\$ 2$ million and "seven days", according to a report from the Brazilian Physics Society. The report, complete with a sketch of a bomb employing $18 \mathrm{~kg}$ of enriched uranium, caused some embarrassment as it was presented by the society to the Secretary of Science and Technology, José Goldemberg, at the same time as the US representative to the International Atomic Energy Agency, Richard Kennedy, was touring Brazil.

The uranium enriching unit is being built by the navy to provide fuel for a submarine reactor. Although the Brazilian constitution requires that nuclear energy be used only for peaceful purposes, Kennedy urged Brazil to ratify the Nuclear Non-Proliferation Treaty. He said that the constitution is for "internal use", and that Brazil could of the University of Cambridge, the earthquake originated in a section of oceanic plate, which is slowly sinking into the mantle. This 'subduction' occurs when oceanic plate is pushed towards a continental plate and burrows underneath.

Subduction in the Carpathian Mountains may now have finished, but a slab of rock has been left protruding almost vertically downwards to a depth of about $100 \mathrm{~km}$. Last week's earthquake probably resulted from part of the leading edge of the slab shearing off along an oblique fault line.

The Vrancea region has a history of earthquakes. Over two thousand people died in the March 1977 tremor, which was twice as powerful as the latest one, but Professor Nick Ambraseys of Imperial that the lower death toll this time was not simply due to the difference in magnitude. In 1977, most deaths were in Bucharest, where old multi-storey concrete buildings, many of which had been weakened by a previous earthquake in 1940 , collapsed. Very few of these vulnerable buildings survived the 1977 earthquake to cause problems last week. Poor building standards were also blamed for the immense loss of life in the 1988 Armenian

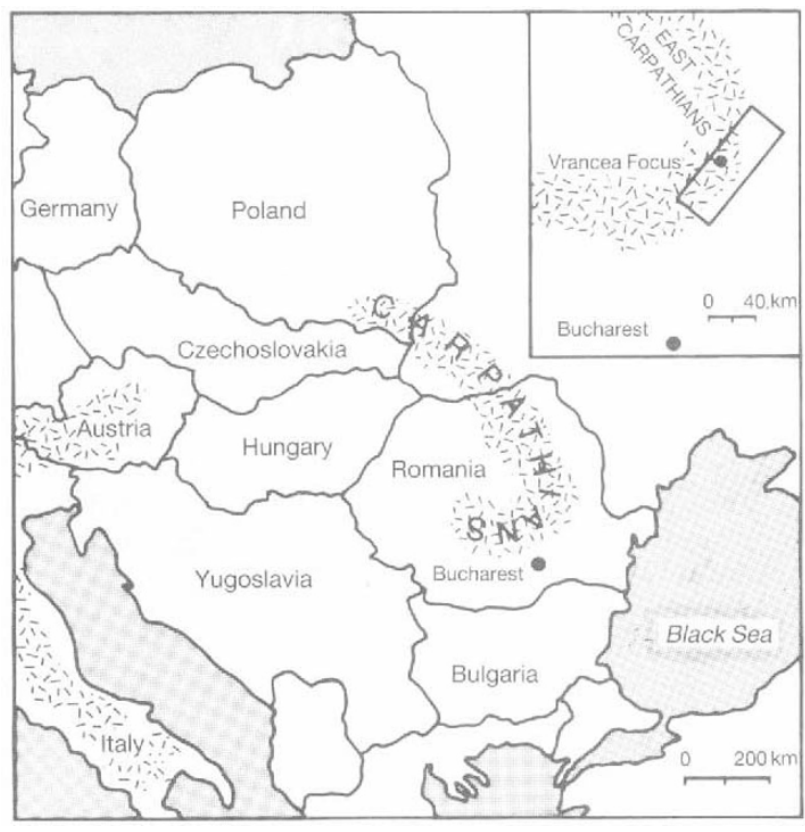

Map of the earthquake area. The slanting rectangle in the map inset marks the approximate position of the subducted oceanic plate, descending into the mantle.

Peruvian earthquakes attracted considerable press attention, Spence says both were dwarfed by a 7.5 magnitude earthquake in a remote area of Sudan, in the African rift valley, on 20 May.

Peter Aldhous

\title{
Brazilian atomic bomb now a possibility
}

show the world its peaceful intentions by signing the non-proliferation treaty.

Brazilian diplomats countered by describing the treaty as "discriminatory". Only if the treaty is changed to improve the exchange of technology between the developed and the developing countries at its next scheduled revision in August would they be willing to sign. The president of the Brazilian National Commission for Nuclear Energy (CNEN), José Luiz de Santana Carvelho, echoed diplomats in denouncing "pressures" for the country to sign and even revived talk of "economic neocolonialism".

Kennedy said that exchange of technology with the United States will not proceed if Brazil does not ratify the treaty, and went on to criticize Brazil's military relations with Iraq. Brazil has long been a major arms exporter to Iraq, selling large quantities of armoured cars and artillery rockets.
Ricardo Bonalume 